\title{
The Salt of the Earth or the Murderess? The Problem of Femininity in the Novels of Agatha Christie
}

\section{Silvia Rosivalová Baučeková}

Pavol Jozef Šafárik University in Košice, Slovakia

Agatha Christie's outlook on gender, as depicted in her novels, has been described as conservative or even criticised as anti-feminist. However, more recently, a growing number of feminist scholars (Alison Light, Susan Rowland, Merja Makinen) have begun to oppose this view and instead argue that Christie's approach to the various social phenomena depicted in her novels, including gender, is more nuanced and ambiguous than previously assumed. This paper explores the role of domesticity in general, and of food, eating and cooking in particular, in constructing such ambiguous portrayal of femininity in three of Agatha Christie's detective novels: Cards on the Table (1936), The Hollow (1946), and 4.50 from Paddington (1957). The novels depict three groups of female characters possessing varying degrees of power and independence: the salt of the earth, i.e., the conservative homemaker, the eccentric, and the murderess. It is the aim of this paper to demonstrate that, paradoxically, it is often through these female characters' roles within the domestic setting and their engagement with food that they are able to overcome the limitations imposed on them by patriarchal society and achieve a certain level of autonomy within it.

\section{Keywords}

Femininity; domesticity; food; Agatha Christie; detective fiction; Golden Age

Agatha Christie's outlook on gender, as depicted in her novels, has been described as conservative or even criticised as anti-feminist by a number of literary critics, including Patricia Craig and Mary Cadogan, Cora Kaplan, and Martin Priestman (Makinen 14-15). However, from the 1980s onwards, a growing number of feminist scholars have begun to oppose this view and 
provide evidence to the contrary, pointing out that Christie was able to create unconventional, or even transgressive female characters, and that she did so purposefully to challenge the social norms of her time. In her book titled Forever England: Femininity, Literature and Conservatism between the Wars (1991), Alison Light examines the role of Christie's female characters and Christie's use of the motif of domesticity in connection with nationalism in inter-war England. In From Agatha Christie to Ruth Rendell: British Women Writers in Detective and Crime Fiction (2001), Susan Rowland demonstrates the transgressive nature of Christie's treatment of class, nation, and gender. Merja Makinen's book Agatha Christie: Investigating Femininity (2006), attempts to prove that Christie's political conservatism was not at odds with "a questioning and even subversive attitude to cultural gender expectations" (1). Although Christie's detective novels are infused with a conservative nostalgia, this nostalgia is presented in a highly ambiguous manner: it is fraught with tension, or even with danger. As Earl F. Bargainnier put it, Christie's novels display a dual character: they are at the same time nostalgic and ironic, conservative and transgressive (Bargainnier 32 ).

It is the aim of this paper to demonstrate how the dual character of Christie's writing is translated into her female characters, as these are frequently the driving force of the feminised detective formula of the Golden Age. In addition, the paper points to the fact that in order to construct her female characters, as well as the stories as such, Christie often relied on domesticity in general, and on food in particular. Here again, the two contradictory connotations of food are emphasised: that of food and foodwork as vehicles of female isolation, subordination, and confinement, versus food and foodwork understood as means of self-expression and power. A majority of Christie's stories are based around women and focus on domesticity, and many of her female characters represent types which reappear in numerous novels. The three novels selected for analysis in this paper, namely Cards on the Table (1936), The Hollow (1946), and 4.50 from Paddington (1957), include a wide array of Christie's typical female characters.

\section{The Golden Age: Feminisation of Crime Fiction}

The beginning of the twentieth century saw a rapid rise in the popularity of genre fiction. However, while spy novels, thrillers and adventure stories were certainly popular at the time, no other genre attracted such a large number 
of readers as the detective novel (Carter and McRae 368). The era between the two world wars is therefore referred to as the Golden Age of crime fiction. In addition to representing a time of peak popularity of detective fiction, the Golden Age was also characterised by the introduction of numerous innovations within the genre.

In the politically and culturally turbulent years at the end of the nineteenth and at the beginning of the twentieth century, the fictional detective assumed the role of a God-like, heroic figure who provided readers with - at least a fictional sense of order (Knight 109). The heroisation of the detective culminated in the character of Sherlock Holmes. The Holmesian formula was soon adopted by a number of other crime authors. Eventually, it became so dominant that writers started to seek ways to escape from this paradigm (Sayers $35^{6}$ ). The changes in the detective genre were also fuelled by the fact that a growing number of women were reading novels at the end of the nineteenth century, and this development went hand in hand with a corresponding increase in the number of female authors. Thanks to the influence of these authors, the crime genre gained new dimensions. Murder, whose feminine, bodily, and bloody character was far removed from the bloodless political intrigues and property crimes of earlier detective stories, gradually became established as the standard crime in detective fiction (Knight $68)$. In addition, authors now tried to make their detectives more unique and human in character (Giddey 66), and they attempted to differentiate them from the cynical "hawk-faced" Sherlock Holmes (Sayers $35^{6}$ ) or the rational thinking-machines of earlier stories.

To accommodate the interests of a generally conservative middle-class female readership, Golden Age crime authors also made changes to the setting of their novels. While crime mysteries originally used to be set in big cities, exploiting the possibility of danger lurking in anonymous dark streets, the Golden Age detective novel is typically set in a familiar or domestic environment, be it a family house, a country mansion, or a small village. The criminals themselves come from this domestic circle: the murder was frequently committed by one of the family members, a close friend, or a lover (Scaggs 46-48). Although on the surface these changes simply seem to cater to the needs of a new female audience, Susan Rowland argues that the matter is not as straightforward as that. She claims that Golden Age female crime authors sought not to replace the masculine with the feminine, but rather to "disrupt the ways in which femininity and masculinity have been previously constructed as mutually exclusive and mutually constitutive" (16). In other 
words, Golden Age authors began to challenge the notion that man is always opposite of woman, i.e., that woman is the man's "other".

Agatha Christie's Poirot is clearly a response to the new trend of feminisation, but he is also a great example of the blurring of boundaries and clear-cut divisions between traditionally masculine and feminine features. Poirot is invariably depicted as fussy, of fragile health and gentle manners, fond of gossip, knowledgeable of the domestic sphere, preoccupied with fashion and his own appearance, and feasting on sweets. In other words, he closely resembles the traditional image of a Victorian lady. He conducts his investigation using the method of abduction, employing not only reason but also intuition (Pascual Soler 7-10), a way of thinking which has traditionally been associated with women. At the same time, he displays some of the qualities traditionally attributed to men: he is infallibly methodical, objective, and unemotional. Christie moved even further on the way towards the feminisation of the detective formula when she created Miss Marple, an elderly spinster who solves domestic crimes in the homes of provincial England. In addition, Christie's novels are populated by numerous minor female characters, and while some of them can be characterised as stock types (such as the man-eater, the fallen woman, and the domestic angel, or as she is called by Christie, the "salt of the earth"), many of these characters do not fit into any of the traditional roles that used to be prescribed for women in Victorian society only a few decades before. In the following sections, I attempt to demonstrate that the unconventional modes of behaviour in which these characters engage are, paradoxically, frequently connected with their role within the domestic setting, especially with food and cooking.

\section{Food, Domesticity, Detection}

Food is a strongly gendered phenomenon. This claim has been proven by the research of scholars from Claude Lévi-Strauss to Warren Belasco and Carole Counihan. These authors have observed that food is loaded with a number of gender associations. Food and reproduction are the two activities that necessarily bring men and women together. They create the need to engage in a collective effort in order to secure sustenance and procreation (Belasco 36 ). Moreover, eating and sexual intercourse exhibit a number of similarities: both involve crossing the boundaries of individual bodies, both are inevitable to sustain life (Counihan 63), both engage the senses, are enacted in a strongly 
intimate setting, and involve the use of the mouth (Belasco 35-36). This interconnection is not only symbolic, but it is also manifested in specific everyday eating habits of women and men. In all cultures, gender identities are constructed through food (Counihan 63): maleness and femaleness are defined by what one is or is not supposed to eat (3). It has been shown that people in Western society have deep-seated beliefs dictating which foods are feminine, which are masculine, and what is (in)appropriate for the members of each sex to consume (Lupton 104). The connection of food and gender is not a neutral one. On the contrary, in Western culture, food has long been considered a domain of women (Counihan 1). In contrast, abstinence from food has been, and still is, understood as a sign of traditionally masculine virtues: intellectualism, rationality, self-sufficiency, and self-control (74).

In addition to their mutual interconnection, both food and femininity are linked to the concept of domesticity and to the traditional image of the home. Home is the place where people are fed as children, where they return to eat as adults, and where they share either everyday or festive meals with family members and close friends. Katherine Hampsten observes that in the twentieth century, American mass media defined domesticity as a force bringing "happiness and fulfilment" to human beings. Moreover, domesticity was equated with "an abundance of food and a well-stocked kitchen", and access to high quality, tasty meals at home was believed to ensure an individual's "contentment and security". Women were understood as the instrumental force in bringing about this idealised domesticity. They were expected to take up the role of cooks or food providers serving meals to others. Cooking and feeding were considered of especially great significance because they were identified as the prerequisites for a successful and content marriage (Hampsten). In other words, domesticity, food, feeding, and women were understood as closely interconnected.

In contemporary food studies discourse, the relationship between women, food, and home has been interpreted in two, seemingly contradictory ways. On the one hand, it has been seen as a reflection of the forceful confinement of women to a domain of lesser importance; to a space where they were unable to articulate their needs and engage in acts of resistance against patriarchal society, which imposed this confinement. On the other hand, scholars acknowledge that women can use, and indeed have used, their influence over the home and over food as a means of self-expression, control, or even rebellion (Belasco 41-49). Sometimes the rebellion assumes the extreme form of eating disorders, when women turn their aggression against their own bodies and either starve 
or fatten themselves in order to escape their subordinated position, which they understand as a result of female sexuality (Counihan 84-91). In other cases, food becomes a method of surveillance over individual family members' behaviour or health, or over household expenses (Belasco 42). Moreover, food, especially the invention, preparation, and circulation of recipes and kitchen gossip, can allow women to communicate with each other and with their communities, give voice to their opinions on various subjects, or even become an outlet of creative self-expression (44). The following section argues that Christie's female characters employ food in all of the above-mentioned ways in order to forge an independent existence for themselves in a society which is to a great extent controlled by men.

\section{Christie's Female Characters: The Salt of the Earth, the Eccentric, and the Murderess}

All of the three novels selected for analysis in this paper depict microcosms dominated by women. In 4.50 from Paddington, an elderly train passenger witnesses a murder, which she reports to Miss Marple, who then hires young, single, and independent Lucy Eyelesbarrow to serve as a spy to help her solve the case. What is more, the investigation takes place in a country house whose only male occupant is the elderly invalid Mr Crackenthorpe. The house is ruled over by his unmarried daughter Emma. While the story of The Hollow revolves around the murder of John Christow, it is the various women related to the deceased who drive the plot, be it his wife Gerda, his lover Henrietta, his former fiancée Veronica, or his distant aunt Lucy. Out of the men present in the story, the only one to parallel the four women in importance is detective Hercule Poirot, who is himself a strongly feminised character. In Cards on the Table, the group of suspects consists of two men and two women, all of whom were already guilty of murder. However, it is significant that both of the two men committed their crimes as a result of disagreements with women.

The women populating the three analysed novels function as main, as well as minor characters. While some of these female characters are depicted as purely negative (e.g., Veronica Cray in The Hollow), a majority of them are portrayed as positive and strong. What is more, even when Christie depicted flawed or weak women, she did not pass moral judgement on them. She portrayed the characters' flaws or failings as caused by circumstances out of their control. Such is the case with Mrs Lorrimer in Cards on the Table, 
who had for reasons unknown to the reader murdered her husband, or with Gerda in The Hollow (see below). In the present analysis, focus is placed on the positively depicted characters, as they form a majority of cases. The analysis examines different types of successful female characters, as well as an unsuccessful one, and attempts to demonstrate how these characters employed food and domesticity in order to influence their own lives and the lives of those around them.

\section{Salt of the Earth: The Conservative Woman}

At first glance, Emma Crackenthorpe from 4.50 from Paddington and Midge Hardcastle from The Hollow appear to conform to the conservative understanding of a woman's role. Emma is a calm, sensitive, and caring angel of the house who never married and devoted her life to taking care of her invalid father. Although Midge was employed at the beginning of the novel, she gave up her job in order to marry the man of her dreams and become a housewife at his country mansion. Both of these characters are described by Christie as "salt of the earth" (The Hollow 298; 4.50 from Paddington 65, 209). They are admired by the other characters, as well as the narrators of the stories, which might indicate that Christie believed such traditional roles to be suitable for women.

However, throughout both of the novels, readers are repeatedly reminded that despite their acceptance of traditional roles, neither Emma nor Midge were passive victims of the social order. On the contrary, both narratives clearly indicate that Emma's and Midge's decisions to take up these roles were willing and deliberate. It is made clear in the course of the story that becoming a caretaker was not Emma's only prospect. Emma received a number of marriage proposals as a young girl, and still had suitors in her middle age. However, she did not wish to marry, nor did she want to leave her home in pursuit of a career. She enjoyed her role as a housekeeper, as it gave her a sense of satisfaction, as well as a certain amount of power over her household, her father, and her brothers. As Inspector Craddock observed, Emma Crackenthorpe was, on the surface, "a quiet woman $[. .$.$] one of those$ comfortable pleasant women whom men were inclined to take for granted, and who had the art of making a house into a home, giving it an atmosphere of restfulness and quiet harmony" (98). However, the Inspector also noticed that Emma's pleasant, obliging demeanour gave her a certain advantage, as 
it enabled her to make her "own plans", keep them to herself, execute them and consequently influence all of the people surrounding her (221).

Angela Meah notes that women who are responsible for providing food for their families frequently hold such silent power over their households. This power is both symbolic and economic, symbolic in that women can use their control over food to bind the family or community together through rituals of "gifting" and "sacrifice" (Meah 676), and economic in that they "often play a significant role in the everyday domestic politics of food allocation within the household" (678). Emma Crackenthorpe did indeed possess both of these types of power. It was Emma who ruled over the household's expenses and decided what food should be served despite the reservations of her tight-fisted father. When her young nephew and his classmate came to visit, she immediately abandoned her father's preferred frugal menus in favour of substantial portions of meat and rich desserts (4.50 from Paddington 55-56). Similarly, she did not hesitate to throw a birthday party with snacks, drinks and even a birthday cake for her suitor Doctor Quimper (262) or invite Miss Marple to tea despite the protests of her brothers (135). When Mr Crackenthorpe complained, even the children who arrived for the holidays knew that one "mustn't pay any attention to [the] grandfather" $\left(5^{6}\right)$. Emma's independence is further highlighted by her attitude towards Doctor Quimper. Although she definitely enjoyed his attention and she even considered accepting his proposal of marriage, if he should give it, she did not rely on him to provide for her future. At the end of the novel, when the doctor turned out to be the one guilty of the murder, Emma was not heartbroken. As Miss Marple put it, the future might still have adventures in store for her: she might inherit money from her elderly father and go on a cruise, move abroad, or even indulge in a romance with a handsome man (271).

Midge from The Hollow represents a reverse case. She was a financially independent employed woman, who decided to pursue a leisurely lifestyle through marriage to a rich man. However, this action is not depicted as unscrupulous or immoral. On the contrary, Midge is always portrayed as driven by duty, be it in her refusal to accept financial support from rich relatives, or in her approach to food:

something in Midge rebelled against the acceptance of ease offered her by her well-to-do relations. To come on rare occasions and sink into the wellordered luxury of Lucy's life was delightful. She could revel in that. But some sturdy independence of spirit held her back from accepting that life 
as a gift. The same feeling had prevented her from starting a business on her own with money borrowed from relations and friends. She had seen too much of that. (146)

To maintain her financial and personal independence, Midge exerted strict control over her body: she had no time for leisurely breakfasts in bed, typical for upper class women (55), her lunch was usually eaten quickly at a snack bar so as not to distract her from work (237), and she often skipped social dinners in order to finish her paperwork (234). In other words, Midge always put her professional duties before her pleasures, thus demonstrating her possession of traditionally masculine virtues of rationality, self-control, and responsibility. When she eventually agreed to marry, it was not simply out of a desire for romance, or in order to secure her living, but rather in the name of duty. Midge discovered that she needed to take care of her future husband, who, as evidenced by his suicide attempt, was unable to do so by himself (275). Thus her final decision, similarly to her eating habits, is proof of her control and superiority, rather than her helplessness or dependence.

\section{The Eccentric: The Independent Woman}

While Emma and Midge, despite their relative independence and power, can be seen as perpetrating the stereotypical understanding of women's roles, the following characters, grouped together under the loose category of female eccentrics, transgress any such roles and find contentment in nontraditional ways of life. The most notable of these examples is Miss Marple, who transformed the traditionally disparaged existence of a spinster into a satisfying lifestyle. All of the props of the spinster: her domesticity, gardening, crocheting, gossiping, and tea-drinking are turned from trivial pastimes into weapons of surveillance which give Marple control over her environment. The helplessness of Marple's social position and her ageing body become a source of power. On multiple occasions throughout the novel, she dons her frailty as a mask, hiding her intellect and detective skills. When talking to suspects and the police, she deliberately plays into the stereotypes held by the other characters, exaggerating her weakness and naivety to avert any suspicion they might harbour. In fact, in 4.50 from Paddington she succeeds at exposing the murderer by pretending to be choking on a fish bone (200-201). She also uses this tactic to overcome socially awkward situations, such as when she 
makes a very shrewd, but unwelcome remark to the Crackenthorpe brothers and then proceeds to embarrass herself by dropping things in order to blunt their displeasure:

Her eyes, gentle and mischievous, went from one to another.

It was clear that she had suggested to them something that they had never thought of and which they did not find overpleasing.

Miss Marple rose to her feet, dropping as she did so, several little woolly scarves and her bag.

The three brothers were most attentive picking things up.

"So kind of you", fluted Miss Marple. "Oh, yes, and my little blue muffler.

Yes - as I say - so kind to ask me here. I've been picturing, you know, just what your home was like - so that I can visualize dear Lucy working here." (107)

Miss Marple also makes good use of her knowledge of domestic details in her investigation. This feminine expertise enables her to collect clues invisible to the masculine police forces, and she wears her spinsterhood as a mask helping her insinuate herself into tea parties and kitchens (e.g., 4.50 from Paddington 134, 136, etc.), where she has access not only to egg and sardine sandwiches, but also to a wealth of seemingly inconsequential gossip. And while the unwitting informers indulge in both, they reveal crucial secrets. As Marple herself pointed out: her mind is like a sink (107), an unassuming and taken-for-granted kitchen fixture, which, however, is able to collect the traces of the whole of a family's private (culinary) life.

Lucy Eyelesbarrow, Miss Marple's helper in 4.50 from Paddington, is similar in her exploitation of overlooked feminine domains - the home, and especially the kitchen - in order to achieve power and independence. Lucy is a thirty-two-year-old Oxford graduate who decided to abandon her successful but low-paying academic career in order to become a professional domestic worker. Thanks to her skill and dedication, Lucy became extremely sought-after, allowing her to choose her employers, travel the world, and earn a considerable sum of money. In other words, Lucy was able to transform the private unpaid labour of cooking and housework into a well-paying job. Mastering stereotypically feminine skills paradoxically enabled her to enter the professional sphere, traditionally reserved for men. As she explained to Cedric Crackenthorpe, she in fact considered the traditional division into 
professional and domestic (or "high" and "low") work an obsolete relic of a bygone age:

"I simply can't make you out", said Cedric Crackenthorpe.

He eased himself down on the decaying wall of a long derelict pigsty and stared at Lucy Eyelesbarrow.

"What can't you make out?"

"What you're doing here."

"I'm earning my living."

"As a skivvy?" He spoke disparagingly.

"You're out of date". said Lucy. "Skivvy, indeed! I'm a Household Help, a Professional Domestician, or an Answer to Prayer, mainly the latter." (113)

The offer to become Miss Marple's spy appealed to Lucy's adventurous spirit. Disguised as cook and housekeeper, she infiltrated the house of rich $\mathrm{Mr}$ Crackenthorpe. Soon, the family became "completely dependent upon her" and were "eating out of her hand": not only metaphorically, but also literally (143), as it was precisely through her cooking skills that she was able to gain the favour of her employers, as well as their guests $(77,114-115$, etc.), and easily collect information. What is more, her status as household help gave her free access to all areas of the house and garden, which she made use of in order to snoop and search for clues $(59,72$, etc.). Access to the kitchen also meant access to the serving staff. This offered yet another opportunity to learn local gossip, which might help her shed more light on the case (58).

In addition to being a useful investigation technique, cooking can also become a means of self-expression for the eccentric female character. This is not only true for Lucy, who claimed that preparing food "satisfie[d] her creative instincts" (149-150), but also for Lady Lucy Angkattel from The Hollow. Lady Angkattel, an elderly aristocrat famous for being an eccentric, used food not only to bind her extended family together during elaborate lunch parties, but also assigned it a symbolic, or even aesthetic function. She chose what food was to be served as if she were selecting the music to be played on various occasions: sandwiches after a murder, because they would go well together with the witnesses' restless mood (117), a caramel custard as a desert after the funeral, because no-one was too fond of it so it would suit the sad atmosphere (128-29), and an apple tart rather than a soufflé for 
Inspector Grange, as it would better complement his temperament and accent his exaggerated Englishness (264). Moreover, Lady Angkattel used food as a tool for misdirection, hiding a gun in a basket of eggs (210) or confusing the police by talk of chocolate cakes (213). Lady Angkattel was such a master of misdirection and ornamentation that she was allowed to transgress most of the social norms which the other characters needed to observe. As her tame husband commented:

"She gets away with things. She always has." He smiled.

"She's flouted the traditions of Government House - she's played merry hell with precedence at dinner parties (and that, Midge, is a black crime!). She's put deadly enemies next to each other at the dinner table, and run riot over the Colour question! And instead of raising one big almighty row and setting everyone at loggerheads and bringing disgrace on the British Raj - I'm damned if she hasn't got away with it!" (58)

Ariadne Oliver, the famous detective fiction author, self-proclaimed feminist, and one of the investigators in Cards on the Table (8) is rather indifferent to domestic issues, however she exhibits a playful approach to food similar to that of Lady Angkattel. For Mrs Oliver, food is not an investigation method or a necessity, but a source of pleasure. She admitted never being able to resist a juicy apple (81) or a nice piece of buttered toast (121). The playful element visible in her relationship to food is also present in her approach to feminism (she preached the need for more women at Scotland Yard [25], and at the same time wore high-heeled shoes to the countryside [82]), to her own writing, and even to the investigation of murder cases. This sense of playfulness permeates the genre of Golden Age detective fiction as such. The novels are frequently labelled clue-puzzles and are constructed as battles of wits between the authors and the readers (Panek 122, 124). According to Rowland, it is exactly this playful spirit which helped Christie to write in an ironic or even self-critical manner, allowing her to transcend the classist and sexist implications of the detective genre (39).

\section{The Murderess: Victim and Villain}

As demonstrated above, a majority of the female characters in the analysed novels were, for the most part, able to transform the limitations of traditional 
female roles into advantages. What is more, they frequently used their close relationship to food as a creative means of achieving independence. However, Christie did not depict only positive female characters. She also portrayed unhappy women or even women who have committed crimes. The same traditional roles that protagonists such as Lucy Eyelesbarrow or Miss Marple take advantage of are frequently the source of misery or failure for the less empowered female characters. However, Christie did not adopt a strictly negative view of these women. On the contrary, in all of the novels analysed here, she refrained from passing moral judgment and depicted the female criminals as victims of their circumstances, such as in the case of Anne Meredith in Cards on the Table, whose complicated family background, poverty, and kleptomania led her to commit a series of murders (e.g., 167).

Gerda Christow, the criminal from The Hollow, is portrayed in an even more sympathetic fashion. Gerda was the perfect specimen of an idealised Victorian version of femininity: she devoted all of her time to her family, she took care of the household, she was meek, submissive, unselfish, and forever understanding of her impatient and moody husband (25). Her oppressed position was embodied in a piece of roast, slowly congealing on the table, while the husband was late for dinner. Because of her absolute dependence on the decisions of her husband, Gerda did not know how to avert the disaster of a cold and tasteless meal that was coming into existence in front of her eyes:

Carve the mutton? But she never could remember which was the right side to plunge the knife in. Of course, perhaps Lewis had put it the right way on the dish - but sometimes she didn't - and John was always annoyed if it was done the wrong way. And, Gerda reflected desperately, it always was the wrong way when she did it. Oh, dear, how cold the gravy was getting a skin was forming on the top of it - she must send it back - but then if John were just coming - and surely he would be coming now. [...] Her mind went round and round unhappily... like a trapped animal. (3234)

In the end, the mutton remained on the table, and by the time dinner was served it had gone completely cold. John, the husband, was irritated (32). Needless to say, this incident did not represent a one-of-a-kind misunderstanding, but rather a pattern which underlay Gerda and John's marriage from its very beginning. Gerda finally lost her patience (or rather overcame her passivity) 
when she and John were invited to a family party, but John left in the middle of the evening to visit one of his former lovers and did not return until the following morning. When Gerda realised he had been cheating on her throughout their marriage, she broke down and shot him. However, even this final, desperate attempt at revenge could not bring her peace, as she was not able to live independently. After committing the crime, she relied on Henrietta, one of John's lovers, to help her hide clues from the police. At the end of the novel, Gerda died after drinking a cup of poisoned tea that she had prepared for someone else (287). However, Poirot decided not to hand proof of her guilt to the police.

\section{Conclusion}

The analysis conducted in the present paper attempted to serve as a counterargument to the claim that Agatha Christie depicted women in a conservative, or even anti-feminist manner. Through the discussion of a number of Christie's female characters' relationship to the two domains traditionally associated with women, i.e., food and domesticity, I sought to demonstrate that Christie created not only dual characters, incorporating innovative and stereotypical depictions of the role of women, but also transgressive ones, for whom she carved out possible alternative roles. For the purpose of the analysis, the female characters were grouped under three categories: the salt of the earth, the eccentric, and the murderess. Women who conform to a rather traditional definition of femininity were examined within the first category. However, as the analysis demonstrated, in spite of the seemingly conservative nature of these characters, Christie depicted them as capable of consciously influencing their destinies. The second group was made up of female characters who chose roles which seemed unusual for women of their time and social class. These characters were invariably depicted as strong and independent, although they expressed their independence in different ways. It is also significant that this group is the largest of all the three analysed groups. The final section was devoted to the case of Greta Christow, a woman destroyed by her adherence to a traditionally feminine role. The character of Greta may be read as Christie's way of pointing out the destructiveness of delegating women to socially subordinate positions. All of the studied examples clearly demonstrate that Christie did not limit her scope to stereotypically feminine characters, nor was she disapproving of successful 
or unusual women. On the contrary, the cast of female characters in her novels are depicted as a diverse group of individuals, trying to navigate the tricky reality of being a woman at the beginning of the twentieth century.

\section{Works Cited}

Bargainnier, Earl F. The Gentle Art of Murder: The Detective Fiction of Agatha Christie. Bowling Green, Ohio: Bowling Green University Popular Press, 1980.

Belasco, Warren J. Food: The Key Concepts. Oxford and New York: Berg, 2008.

Carter, Ronald and John McRae. The Routledge History of Literature in English. 2nd ed. Oxon: Routledge, 2001.

Christie, Agatha. 4.50 from Paddington. London: HarperCollins, 2011 (1957).

---. Cards on the Table. New York: Berkley Books, 1997 (1936).

---. The Hollow. New York: HarperCollins, 2011 (1946).

Counihan, Carole M. The Anthropology of Food and Body: Gender, Meaning, and Power. New York and London: Routledge, 1999.

Giddey, Ernest. Crime et detection: Essai sur les structures du roman policier de langue anglaise. Berne: Peter Lang, 1990.

Hampsten, Katherine. "Serving Family, Serving Country: Visual Images of Cold War Domesticity in Seventeen Magazine." Women and Language, n. pag, 2013.

Knight, Stephen. Crime Fiction, 1800-2000: Detection, Death, Diversity. Basingstoke: Palgrave MacMillan, 2004.

Lévi-Strauss, Claude. "The Culinary Triangle." Food and Culture: A Reader (Second Edition), edited by Carole M. Counihan and Penny van Esterik, New York: Routledge, 2008 (1966), pp. 36-43.

Light, Alison. Forever England: Femininity, Literature and Conservatism between the Wars. Abingdon, Oxon: Routledge, 1991.

Lupton, Deborah. Food, the Body and the Self. London: Sage Publications, 1996.

Makinen, Merja. Agatha Christie: Investigating Femininity. Houndmills, Basingstoke: Palgrave, 2006.

Meah, Angela. "Reconceptualizing Power and Gendered Subjectivities in Domestic Cooking Spaces." Progress in Human Geography, 38.5, 2014, pp. 671-69o. 
Panek, LeRoy Lad. An Introduction to the Detective Story. Bowling Green, Ohio: Bowling Green State University Popular Press, 1987.

Pascual Soler, Nieves. A Critical Study of Female Culinary Detective Stories: Murder by Cookbook. Lewiston: The Edwin Mellen Press, 2009.

Rowland, Susan. From Agatha Christie to Ruth Rendell: British Women Writers in Detective and Crime Fiction. Houndmills, Basingstoke: Palgrave, 2001.

Sayers, Dorothy L. "The Omnibus of Crime." Detective Fiction: Crime and Compromise, edited by Dick Allen and David Chacko, San Diego: Harcourt Brace Jovanovich, 1974 (1929), pp 351-383.

Scaggs, John. Crime Fiction: The New Critical Idiom. Oxon: Routledge, 2005.

SILVIA ROSIVALOVÁ BAUČEKOVÁ is Assistant Professor at Pavol Jozef Šafárik University in Košice, Slovakia. As a doctoral student, she took an interest in the emerging field of food studies. Her research focused on the symbolic role of food in detective fiction was published as a monograph titled Dining Room Detectives: Analysing Food in the Novels of Agatha Christie. She continues to explore the possibilities of analysing food imagery in fictional and non-fictional texts. She has studied the role of domestic spaces in women's fiction, and the representation of women in healthy eating discourse. Recently, she has pursued these interests as a Fulbright visiting scholar at the University of Oregon. Her other research interests include gender studies and popular fiction studies. She is a member of the Slovak Association for the Study of English and the Association for the Study of Food and Society. silvia.baucekova@upjs.sk 